\title{
The pathogenetic substantiation for using ozone therapy in patients of the puerperal period complicated by Gram-negative sepsis
}

\author{
Gennadiy Andreevich Boyarinov, Larisa Valentinovna Boyarinova, Victoria Evgenievna Kucherenko, \\ Roman Romanovich Zaytsev
}

The Nizhny Novgorod State Medical Academy, The Nizhny Novgorod Regional Clinical Hospital named after N.A. Semashko, Russia

\begin{abstract}
The study involved 29 patients of the puerperal period complicated by Gram-negative abdominal sepsis. The complex intensive therapy for the postoperative patients included the daily intraaortal infusion of $400 \mathrm{ml}$ of ozonated saline solution (OSS) at the ozone concentration of $10.5 \mathrm{mg} / \mathrm{l}$ within 5 days. On the first and on the fifth day after surgery the content of gram-negative bacteria lipopolysaccharide (LPS) in blood, metabolism products of nitrogen oxide $(\mathrm{NO})$ - nitrites and nitrates, substances with low and medium molecular weight (SL\&MMW) in plasma, erythrocytes and urine was determined before, at the end of and 1 and 4 hours after the OSS infusion. It was found that the main pathogenetic mechanisms of the ozone therapy for patients with Gram-negative sepsis was the direct oxidative effect of ozone on the Gram-negative bacteria LPS and SL\&MMW and that the LPS oxidative breakdown with ozone causes the decrease in the NO production and, therefore, to the reduced contents of nitrates and nitrites.
\end{abstract}

KEY WORDS: ozone therapy mechanisms, abdominal sepsis, puerperal period.

ADDRESS FOR CORRESPONDENCE: Gennadiy Andreevich Boyarinov, The Nizhny Novgorod State Medical Academy, The Nizhny Novgorod Regional Clinical Hospital named after N.A. Semashko, Russia, e-mail: Boyarin46@mail.ru

\section{INTRODUCTION}

The research of the recent decade has shown the significant attainments in the comprehension of the sepsis pathogenesis, especially obvious in a disease provoked by a Gram-negative flora. The role of lipopolysaccharide (LPS) as a component of the inner bacterial envelope named endotoxin was determined in the development of a pro-inflammatory cascade and in the subsequent multiple organ failure in patients with sepsis. Endotoxin combined with a lipopolysaccharide-binding protein is capable of interacting with specific receptor CD14 located on the surface of macrophages. It is followed by their activation, cytokine synthesis, nitric oxide (NO), by the formation of endotoxemia and the septic shock development $[1,2]$. It is known that the ozone therapy has been successfully used as a method of detoxification for various pyoinflammatory diseases $[3,4]$. In view of the key role of endotoxin, nitrogen oxide and increasing endotoxemia in the development of septic shock and multiple organ failure it is necessary to assess the effect of the ozone therapy on these pathogenetic factors.

The purpose of the study was to determine the effect of ozonated saline solution on the contents of LPS, metabolic products of NO and the level of endotoxemia in patients with Gram-negative sepsis.

\section{MATERIAL AND METHODS}

Twenty-nine patients were examined in the puerperal period complicated by Gram-negative abdominal sepsis. The surgical tactics, the scope of the operative intervention 
in patients were aimed at the removal of the primary focal point of infection, the exudate evacuation, the single-step lavage and the abdominal cavity drainage. In the first 8-12 hours after the transfer of patients from the operating room to the intensive care unit and after the correction of gross violations of hemodynamics by Seldinger's technique the aorta catheterization was performed through femoral access by placing a radiopaque catheter at the level of TVII, which was proved by the chest X-ray. The postoperative intensive therapy was performed by the intraaortic administration of drugs and included a complex of antibacterial chemotherapy based on the results of clinical examinations and bacteriological tests, the maintaining of hemodynamics and microcirculation, water-electrolytic and acid-base balance. $400 \mathrm{ml}$ of ozonated saline solution (OSS) at the ozone concentration of $10.5 \mathrm{mg} / \mathrm{l}$ was also daily infused into the aorta within 5 days. The daily infusion volume was $50-60 \mathrm{ml} / \mathrm{kg}$. Blood preparations and fat emulsion were administered intravenously.

The LPS level monitoring in Gram-negative bacteria was performed by using a diagnostic kit $\mathrm{MACH}$-endotox spp. test (of SEI A.M. Bakulev NCVSC of the RAMS, SPF ROHAT LLC, Russia). The metabolic products of nitrogen oxide were assessed as per the nitrite and nitrate contents [5]. To assess endotoxicosis and its compensation by renal excretion, the content of substances with low and medium molecular weight (SL\&MMW) was determined in plasma, erythrocytes and urine [6] and the calculation of the endogenous intoxication syndrome index (EISI) was performed as follows: EISI = SL\&MMW of pl. $\times$ SL\&MMW of er./SL\&MMW of urine (the norm was $5.32 \pm 0.48$ ). The above indicators were examined before, at the end of and in 1 and 4 hours later the OSS infusion on the first and fifth day after surgery.

The statistical processing of the results of the study was carried out by using parametric and non-parametric methods of statistical variance. The calculation of statis- tical parameters was made in the Microsoft Excel environment.

\section{RESULTS AND DISCUSSION}

A number of clinical tests show the important predictive role of determining the level of endotoxin in patients' blood serum prior to starting the intensive therapy, as there is the direct dependence of the multiple organ failure and a poor outcome of the disease on its initial level [1,7-9].

On the first day after the surgery the LPS content in the patients' blood far exceeded its normal background values. After the intraaortic OSS infusion the LPS level in venous blood decreased by $71.2 \%$, and in 1 and 4 hours after the infusion its content was also found quite significantly lower than the initial values by $66.7 \%$ and $45.8 \%$, respectively (Table 1 ). The increasing LPS level after the OSS infusion was apparently associated with the improved microcirculation in an infectious focus and, therefore, with endotoxin washing-out and supply into the vascular bed.

The high LPS sensitivity to the oxidation by ozone is associated, in our opinion, with the structural features of an endotoxin molecule. Endotoxin is a polymer, which biological activity depends greatly on its lipid component (lipid A) consisting of disaccharide, phosphate and fatty acids $[1,9]$. The $\mathrm{C}=\mathrm{C}$ double bonds in fatty acids (lipid A) of endotoxin are the reactive center for ozone. In the process of ozonolysis fatty acid chains are broken with forming hyperoxides, peroxides and joining the $\mathrm{OH}$ group. As a result of these reactions a fat-soluble endotoxin substance is transformed into a water-soluble one and is excreted with urine.

An O-specific lipopolysaccharide chain is the most variable part of a LPC molecule built up from the repeating oligosaccharide: glucose, galactose, rhamnose. This part adds some hydrophilic properties to LPS, thus

TABLE 1. The dynamics of lipopolysaccharide (LPS), metabolic products of nitrogen oxide and the level of endotoxemia in patients' blood with the ozonated saline solution (OSS) infusion ( $\pm \pm m$ )

\begin{tabular}{|l|c|c|c|c|}
\hline \multirow{2}{*}{ Index } & \multicolumn{4}{|c|}{ Stages of the study } \\
\cline { 2 - 5 } & before the OSS & at the end the & \multicolumn{2}{|c|}{ after the OSS infusion } \\
\cline { 3 - 5 } & infusion & OSS infusion & 1 hour later & 4 hours later \\
\hline LPS (pkg/ml) & $68.57 \pm 9.25$ & $19.71 \pm 2.28^{\circ}$ & $22.86 \pm 3.28^{\circ}$ & $37.14 \pm 7.44^{\circ}$ \\
\hline Arterial blood nitrates/nitrites (mmol/l) & $35.06 \pm 3.05$ & $29.76 \pm 3.09$ & $27.58 \pm 2.96^{\circ}$ & $27.65 \pm 2.45^{\circ}$ \\
\hline Venous blood nitrates/nitrites (mmol/l) & $49.98 \pm 2.47^{*}$ & $37.51 \pm 3.05^{\circ} *$ & $30.40 \pm 2.88^{\circ} *$ & $33.79 \pm 2.97^{*} *$ \\
\hline SL\&MMW (pl., c.u.) & $29.16 \pm 1.36$ & $26.39 \pm 1.01^{\circ}$ & $26.20 \pm 1.35^{\circ}$ & $26.25 \pm 1.23^{\circ}$ \\
\hline SL\&MMW (er., c.u.) & $32.17 \pm 1.21$ & $28.19 \pm 1.33^{\circ}$ & $26.62 \pm 1.55^{\circ}$ & $27.23 \pm 1.24^{\circ}$ \\
\hline SL\&MMW (urine, c.u.) & $36.70 \pm 1.39$ & $37.03 \pm 1.74$ & $42.62 \pm 1.20^{\circ}$ & $43.32 \pm 1.37^{\circ}$ \\
\hline EISI 238-306 (nm, c.u.) & $25.91 \pm 1.03$ & $20.14 \pm 1.86^{\circ}$ & $17.53 \pm 1.47^{\circ}$ & $16.50 \pm 1.43^{\circ}$ \\
\hline
\end{tabular}

Note: ${ }^{0}$ - the validity of results as compared to initial values; ${ }^{*}$ - the validity of differences in venous blood values as compared to arterial ones at the same stage of research. 
ensuring their high water solubility and therefore, the rapid spread in the patient's body and the progressive multiple organ injury in case of generalized Gram-negative infections. When oligosaccharides are exposed to ozone their oxidative breakdown occurs followed by the formation of aldehydes, ketones and acids, which are removed easier than oligosaccharides from the patient's body with urine.

In analyzing the above findings it is logically to conclude that the intraaortal OSS infusion has a direct oxidative effect on lipid A and on the O-specific chain of oligosaccharides comprising LPS of Gram-negative bacteria. It results in the reduction of endotoxin level in the blood of patients with Gram-negative sepsis. We should note the particular importance of the LPS reduction we revealed in blood due to the oxidative effect of ozone on endotoxin and the development of multiple organ disorders. The reducing of the endotoxin level in patients' blood is accompanied with decreasing mortality [8, 10-12].

As known, in septic conditions the $\mathrm{NO}$ production is sharply increased as a result of the activation of inducible NOS by the bacterial endotoxin - LPS $[2,13,14]$. The NO hyperproduction in phagocytes has an effect on the pathogen neutralization process. The antimicrobial action is based on the ability of the NO intermediate reactive products to cause the nitrosylation and deamination of proteins, the oxidative damage and disruption of the DNA repair system $[13,14]$. A NO molecule is one of the bioregulators of the blood vessel tone. It is involved in the pain development. The NO cytotoxic effect is enhanced due to its ability to react with a superoxide radical causing the formation of peroxynitrite, which has a far higher reactivity than NO or a superoxide radical separately. Nitrogen oxide activates the soluble guanylate cyclase in endothelial cells of blood vessels and it results in the synthesis of guanosine monophosphate. The latter causes the relaxation of vascular smooth muscle cells as a result thereof the vascular permeability increases $[12,13]$. Endothelial cells become "leaky", thereby exuding liquid, plasma proteins and white blood cells. Nitrogen oxide plays a crucial role in the development of septic shock $[11,15]$.

When assessing the dynamics of nitrite $\left(\mathrm{NO}_{2}\right)$ / nitrate $\left(\mathrm{NO}_{3}\right)$ contents in the venous and arterial blood of patients the following regularities were revealed. Before the OSS infusion a high level of NO metabolite contents was found both in the arterial and venous blood. That was due to the fact that in inflammatory processes the production of a superoxide anion radical by macrophages and polymorphonuclear neutrophils greatly increases, the long enhancement of the NO synthesis occurred. The values of venous figures exceeded the arterial ones and that may be associated with the increased NO production in the systemic circulation in abdominal sepsis. At the end of the intraaortal OSS infusion the reduction of $\mathrm{NO}_{2} / \mathrm{NO}_{3}$ was noted by $15.1 \%$ in the arterial blood and by $25 \%$ in venous blood with significant differences of arteriovenous indices from the initial values. One hour later the OSS infusion the significant reduction of $\mathrm{NO}_{2} / \mathrm{NO}_{3}$ in the venous and arterial blood went on with the reduction of the arterio-venous difference. The reduction of $\mathrm{NO}_{2} / \mathrm{NO}_{3}$ during and after the OSS infusion was the proof of the direct and delayed action of the ozone therapy on products of nitric oxide metabolites.

In 4 hours later the OSS infusion the tendency to increasing of the $\mathrm{NO}_{2} / \mathrm{NO}_{3}$ values in the venous blood was noted, but the significant differences (by 32.4\%) remained as compared to the initial values. The increase in arteriovenous differences of NO was only associated with the increase in venous indicators of $\mathrm{NO}_{2} / \mathrm{NO}_{3}$, which coincided by time with the increase of the endotoxin level in the venous blood.

Metabolic disorders in sepsis result in the formation and supply to the blood flow of a large quantity of protein substances with a molecular weight of 300 to $5000 \mathrm{D}$, for which the term SL\&MMW is used [16-18]. SL\&MMW with their high-grade biological activity show toxic properties causing together with other factors the development of immunodeficiency, suppress the transformation and inhibit the phagocytic activity of lymphocytes, promote the hemolysis of red blood cells. The excessive accumulation of SL\&MMW in the body areas is first of all associated with the activation of proteolytic processes as well as with the violation of the SL\&MMW excretion from the body because of the detoxification dysfunction. The determination of the SL\&MMW concentration in biological media of the body is one of the informative and accessible ways to assess the degree of endogenous intoxication $[19,20]$.

Before the OSS infusion in patients with Gram-negative sepsis the endotoxemia decompensation was found due to the of accumulation of the SL\&MMW of plasma and red blood cells (more than 29 c.u. and 32 c.u. respectively) and their reduced elimination with urine (less than 37 c.u.). The mean EISI was 25.9 c.u.

At the end of the OSS infusion the significant reduction of the plasma SL\&MMW (by 9.5\%), SL\&MMW in red blood cells (by 12.4\%) and the increase in the urine SL\&MMW by $1 \%$ was noted. The EISI decreased by $22.3 \%$. Hence, during the OSS infusion the direct oxidation of endotoxins by ozone occurred causing the reduction of the SL\&MMW content in plasma and to a greater extent on erythrocytes. The increased oxidative therapy tropism to the red blood cell SL\&MMW has been earlier described by Wexler et al. [21]. In our opinion, it was also closely related to the reaction of ozone and erythrocyte glycocalyx, which is particularly rich in double bonds and it transports on its surface due to various sorption mechanisms a large number of substances of different etiologies included in SL\&MMW [6].

In 1 and 4 hours later the OSS infusion both direct and indirect detoxifying effects of the ozone therapy 
were displayed. The reduced values of SL\&MMW in plasma and in red blood cells and the increased ones in urine were found as compared to initial values. The additional increase of endotoxuria enabled to enhance the degree of the endotoxemia compensation in 1 hour and especially 4 hours after the OSS infusion. The EISI decreased respectively by $32.4 \%$ and $36.3 \%$.

The endotoxicosis compensation in patients with Gram-negative sepsis occurs due to the interaction of ozone with the $\mathrm{C}=\mathrm{C}$ double bonds of fat-soluble SL\&MMW. In the course of ozonolysis fatty acid chains are broken with forming hyperoxides, peroxides and joining the $\mathrm{OH}$ group. As a result of these reactions fat-soluble toxic substances are transformed into water-soluble ones and they excrete with urine, i.e. the oxidation of xenobiotics by ozone results in the formation of end products similar to those obtained with the involvement of cytochrome P-450 in the liver. Therefore, the administration of ozone into the blood flow may simulate the monooxygenase detoxifying system of the liver [21]. When analyzing the results of the endotoxemia study it may be concluded that ozone by oxidizing large hydrophobic and hydrophilic molecules transforms them into substances with a molecular weight below $500 \mathrm{D}$ [9]. These substances do not relate to "middle molecules" and are easily excreted by the kidneys.

The regularity of changes in parameters under the study with the OSS infusion was on the fifth day of treatment the same as on the first day, but their value was less determined.

\section{CONCLUSIONS}

The basic pathogenetic mechanisms of the ozone therapy for patients with Gram-negative sepsis is the direct oxidative effect of ozone on the Gram-negative bacteria LPS and SL\&MMW and the LPS oxidative breakdown by ozone causes the decrease in the NO production and, therefore, the reduced content of nitrates and nitrites.

\section{DISCLOSURE}

Authors report no conflict of interest.

\section{References}

1. Беляков НА. Верификация эндотоксикоза у больных с разлитым перитонитом. Эфферентная терапия 1995; 2: 31-34.

2. Гельфанд БР, Гологорский ВА, Гельфанд ЕБ. Стратегия и тактика антибактериальной терапии абдоминального сепсиса. Анестезиология и реаниматология 1998; 2: 23-29.

3. Бояринов ГА, Рябов СВ, Серова АН, и соавт. Тез. докл. 4-й Всероссийской науч. - практ. конф. “Озон и методы эфферентной терапии в медицине”. Н. Новгород 2000; 6-7.

4. Векслер НЮ. Озонотерапия в комплексе детоксикации у больных с заболеваниями брюшной полости, осложненными диффузным перитонитом. Озон и методы эфферентной терапии в медицине: Мат. IV Всеросс. науч.-практ. конф. 2000, Нижний Новгород; 71-72.
5. Green DR, Kroemer J. The pathophysiology of mitochondrial cell death. Science 2004; 305: 626-629.

6. Малахова МЯ. Эндогенная интоксикация как отражение компенсаторной перестройки обменных процессов в организме. Эфферентная терапия 2000; 4: 3-14.

7. Balci C, Sungurtekin H, Gurses E, et al. Usefulness of procalcitonin for diagnosis of sepsis in the ISU. Crit Care 2003; 7: 85-90

8. Bone RC, Balk RA, Cerra FB. Definitions for sepsis and organ failure and guidelines for the use of innovative therapies in sepsis: the ACCD/SCCM consensus conference committee. Chest 1992; 101: 1644-1655.

9. Shoji H. Extracorporeal endotoxin removal for the treatment of sepsis: endotoxin adsorption cartridge (toraymyxin). Ther Apher Dial 2003; 7: 108-114.

10. Яковлев АЮ. Применение высоких концентраций озона в растворе в интенсивной терапии. Озон в биологии и медицине: Мат. VI Всеросс. науч.-практ. конф. международным участием 2005; Нижний Новгород; 159.

11. Beal AL, Cerra FB. Multiple organ failure syndrome in the 1990s: systemic inflammatory response and organ dysfunction. JAMA 1999; 279: 226-280.

12. Beckmann JS, Koppenol WH. Nitric oxide, superoxide and peroxynitrite: the good, the bad and ugly. Am J Physiol 1996; 271: 1424-1437.

13. Реутов ВП, Соркина ЕГ, Охотин ВЕ, Косицын НС. Циклические превращения оксида азота в организме млекопитающих. М.: Наука 1997; 165.

14. Сосунов АА. Оксид азота как межклеточный посредник. Соросовский образовательный журн 2000; 6: 27-34.

15. Balk R. Severe sepsis and septic shock. Definition, epidemiology and clinical manifestation. Crit Care Clin 2000; 17: 214-226.

16. Гаврилов ВБ, Бидула ММ, Фурманчук ДА и др. Оценка интоксикации организма по нарушению баланса между накоплением и связыванием токсинов в плазме крови. Клин. лаб. диагн. 1999; 2: 13-17.

17. Корякина ЕВ, Белова СВ. Молекулы средней массы как интегральный показатель метаболических нарушений (обзор литературы). Клин. лаб. диагн. 2004; 3: 3-7.

18. Малахова МЯ. Метод регистрации эндогенной интоксикации: Пособие для врачей. С-Петербург, МАПО 1995; 33.

19. Дорохин КМ, Спас ВВ. Патофизиологические аспекты синдрома эндогенной интоксикации. Анестезиология и реаниматология $1994 ; 1: 56-60$.

20. Малахова МЯ, Оболенксий СВ. Лабораторная диагностика интоксикации в практике интенсивной терапии: Методическое пособие. С-Петербург, МАПО 1993; 16.

21. Векслер НЮ. Применение гипохлорита натрия и озонированного физиологического раствора в комплексе интенсивной терапии у больных инфекционным эндокардитом: Автореф. дисс. ...канд. мед. наук. Москва 1998.

22. Бояринов ГА, Векслер НЮ, Бояринова ЛВ, Юрьев МЮ и др. Детоксицирующее действие озона. Казанский медицинский журнал 2007; 88: 261-263 